\title{
IMPLEMENTASI KONSEP PARIWISATA BERBASIS MASYARAKAT DALAM PENGELOLAAN PANTAI KEDONGANAN
}

\author{
Anom Hery Suasapha \\ Email: anom_hs@yahoo.com
}

\begin{abstract}
Kedonganan beach is a tourist destination located in Kedonganan Village, South Kuta, Bali, known for its scenic beauty and the culinary activity. The beach was a fisherman village, until tourism developed in the area during 1995. The tourism development was not a carefully planned, resulted in many negative effects on the area and also to the community. A correction plan was developed based on Community Based Tourism (CBT) concept, and has been implemented since 2006. This article discusses the implementation process of community based tourism (CBT) in Kedonganan Beach. The enabling factors and the barrier of the implementation are also discussed, and the model of CBT implemented in the area are developed and discussed. The analysis result shows that implementation of CBT concept in the management of Kedonganan has been done in two steps. These steps were devided into smaller steps, in which four CBT principles were implemented. Local inisiative, support from Badung Regency Government and social capital were some of the factors that enables the implementation of CBT concept in Kedonganan Beach, while rejection from some of the community member and different perception of the community toward the lagal status of the land were the barriers of the implementation.
\end{abstract}

Keywords: Kedonganan Beach, community based tourism, implementation, enabling and barrier factors, CBT Model

\section{Pendahuluan}

Pariwisata berbasis masyarakat (Community Based Tourism/CBT) merupakan konsep pengembangan kepariwisataan yang berkesesuaian dengan pariwisata berkelanjutan. Konsep tersebut mengedepankan partisipasi aktif masyarakat dengan tujuan untuk memberikan kesejahteraan bagi mereka dengan tetap menjaga kualitas lingkungan, serta melindungi kehidupan sosial dan budayanya, sehingga implementasinya mampu mendukung tercapainya tiga pilar keberlanjutan (the three pillars of 
sustainability) yaitu keberlanjutan di bidang ekonomi, sosial-budaya dan lingkungan (Asker et al, 2010).

Pariwisata berbasis masyarakat merupakan bentuk pariwisata berkelanjutan. Meskipun demikian, ada perbedaan mendasar di antara kedua konsep tersebut, pariwisata berbasis masyarakat mengedepankan pendekatan bottom-up, sedangkan pariwisata berkelanjutan mengedepankan pendekatan top-down (Tasci et al, 2013). Pendekatan bottom-up mengandung arti bahwa inisiatif untuk pengembangan pariwisata berasal dari masyarakat, sedangkan pada pendekatan top-down, inisiatif berasal dari pemerintah.

Pariwisata berbasis masyarakat bukanlah konsep yang kaku. Penerapan konsep pariwisata berbasis masyarakat harus disesuaikan dengan karakteristik suatu destinasi, baik kondisi fisik, masyarakat, pemangku kepentingan, dan sistem ekonominya. Penyesuaian tersebut diperlukan mengingat setiap destinasi memiliki keunikan masing-masing sehingga berbeda satu dengan lainnya. Perbedaan karakteristik destinasi tersebut mengakibatkan tidak ada model pariwisata berbasis masyarakat yang langsung dan secara tepat dapat diimplementasikan di destinasi berbeda tanpa melalui penyesuaian-penyesuaian (Tasci et al, 2013: 12-19).

Penelitian di bidang pariwisata berbasis masyarakat telah banyak dilakukan, seperti oleh Arif Satria et al (2005), Raja Othman at al (2011), Lopez-Gusman et al (2011), Sri Widowati (2012), dan Nurhidayanti (2013). Penelitian-penelitian tersebut lebih banyak berfokus dalam membahas partisipasi masyarakat sebagai salah satu prinsip dalam pengembangan pariwisata berbasis masyarakat. Prinsip pengembangan pariwisata berbasis masyarakat lainnya tidak banyak diulas, terkecuali oleh Nurhidayanti (2013). Selain itu gambaran mengenai proses implementasi secara menyeluruh yang dapat memberikan pemahaman mengenai langkah-langkah, kendala yang dihadapi maupun faktor pendukung penerapan konsep pariwisata berbasis masyarakat, hingga model yang diimplementasikan juga tidak banyak diteliti.

Pantai Kedonganan merupakan sebuah daya tarik wisata yang terletak di Kelurahan Kedonganan, Kecamatan Kuta, Kabupaten Badung, Bali. Pantai tersebut setiap hari ramai dikunjungi wisatawan (lokal, nasional, internasional) sebagai tempat untuk menikmati makan malam di puluhan kafe yang menjual makanan hasil olahan ikan laut (sea food). Kafe tersebut dibangun di atas lahan sempadan Pantai Kedonganan yang sesungguhnya statusnya merupakan tanah negara dan juga tanah ulayah (tanah milik masyarakat hukum adat) Desa Adat Kedonganan.

Kafe yang ada di Pantai Kedonganan berjumlah 24 buah. Seluruhnya merupakan milik 24 kelompok pemilik kafe yang anggotanya merupakan seluruh warga Desa Adat Kedonganan (1257 KK) dan tersebar di 6 banjar, 
yaitu Banjar Anyar Gede, Banjar Kerthayasa, Banjar Pengenderan, Banjar Pasek, Banjar Ketapang dan Banjar Kubu Alit.

Sebagai sebuah daya tarik wisata berbasis masyarakat, Pantai Kedonganan telah menempuh perjalanan yang cukup panjang. Semenjak perkembangan awalnya pada tahun 1995 sampai tahun 2006, kepariwisataan di Pantai Kedonganan menghadapi berbagai masalah lingkungan, sosialbudaya dan ekonomi. Seluruh permasalahan bersumber dari tidak adanya perencanaan yang matang terhadap perkembangannya. Setelah penataan ulang dilaksanakan semenjak tahun 2006, berbagai dampak buruk dari keberadaan 76 kafe mulai dapat diatasi, dan kesejahtareaan warga Desa Adat Kedonganan secara umum telah jauh meningkat.

Penelitian yang membahas mengenai penerapan pariwisata berbasis masyarakat di Pantai Kedonganan belum banyak dilakukan. Beberapa penelitian mengenai kepariwisataan di Pantai Kedonganan yang berhasil ditelusuri, lebih mengkaji Kedonganan dari aspek strategi pengembangan serta dari aspek hukum, seperti yang dilakukan oleh Sucipta (2012) dan Sardana (2013).

Artikel ini ditulis berdasarkan hasil penelitian yang mengkaji implementasi konsep pariwisata berbasis masyarakat dalam pengelolaan kepariwisataan di Pantai Kedonganan. Artikel ini diharapkan dapat menggambarkan dengan jelas proses penerapan, kendala yang dihadapi dalam penerapan maupun faktor pendukung penerapan pariwisata berbasis masyarakat di Pantai Kedonganan. Selain itu, artikel ini juga merumuskan sebuah model pengembangan pariwisata berbasis masyarakat berdasarkan pengalaman penerapannya di Pantai Kedonganan.

\section{Pariwisata Berbasis Masyarakat dan Partisipasi Masyarakat}

Pariwisata berbasis masyarakat merupakan jenis kepariwisataan yang mengedepankan partisipasi masyarakat dalam perencanaan, pengembangan, pengelolaan dan kepemilikan (Hausler and Strasdas, 2003; Asker et al, 2010; UNWTO-STEP Foundation, 2011; Tasci et al, 2013). Selain partisipasi masyarakat, karakteristik lain dari pariwisata berbasis masyarakat adalah berskala kecil, adanya unsur edukasi dan interpretasi dalam produknya, mempromosikan pentingnya konservasi terhadap lingkungan, sosial dan budaya (Hausler \& Strasdas, 2003).

The Mountain Institute (2000) menyatakan bahwa pariwisata berbasis masyarakat harus berkontribusi dalam memberikan manfaat ekonomi bagi masyarakat lokal serta menyediakan produk yang bertanggung jawab secara sosial dan lingkungan.

Arnstein (1969) menyatakan bahwa partisipasi masyarakat merupakan pendistribusian kembali kemampuan/kekuatan kepada seluruh anggota masyarakat sehingga mampu untuk mencapai sesuatu. Arnstein membagi partisipasi masyarakat menjadi delapan tipe, yang disusun seperti susunan 
tangga (ladder of participation). Tangga terbawah menunjukkan tipe partisipasi dengan kadar paling rendah, dan semakin tinggi posisi anak tangga, semakin tinggi pula kadar partisipasinya.

Delapan tipe partisipasi menurut Arnstein dari kadar terendah sampai tertinggi adalah: manipulation, theraphy, informing, consultation, placation, partnership, delegated power, dan citizen control. Delapan tipe partisipasi tersebut dibagi lagi oleh Arnstein menjadi tiga kelompok tipe partisipasi. Tipe manipulation dan theraphy dikelompokkan sebagai "nonparticipation", tipe informing, consultation dan placation dikelompokkan sebagai "degrees of tokenism"; dan partnership, delegated power, dan citizen control dikelompokkan sebagai "degrees of citizens power".

Pretty (1995) membagi partisipasi menjadi tujuh tipe, terdiri atas manipulative participation, passive participation, participation by consultation, participation for material incentives, functional participation, interactive participation dan self mobilization. Manipulative participation merupakan tipe partisipasi yang paling tidak diinginkan, sedangkan self mobilization merupakan tipe yang paling diinginkan. Tipologi partisipasi masyarakat yang dikemukakan oleh Pretty (1995) menekankan mengenai pentingnya motivasi dalam penerapan pendekatan partisipasi, sedangkan tipologi Arnstein (1969) menunjukkan bahwa partisipasi pada dasarnya berkaitan dengan kemampuan dan control (Cornwal, 2008).

Keikutsertaan masyarakat (partisipasi masyarakat) merupakan salah satu karakteristik penting dari pariwisata berbasis masyarakat. (Hausler \& Strasdas, 2002; Asker et al, 2010; Tasci et al, 2013). Partisipasi masyarakat dalam setiap tahapan pengembangan kepariwisataan di destinasi pariwisata bahkan dikatakan sebagai syarat utama keberhasilannya (Pitana 1999, dalam Prasiasa, 2013).

\section{Modal Sosial}

Modal Sosial (social capital) merupakan sebuah konsep yang berkaitan dengan kehidupan sosial manusia, keterhubungan mereka serta pengaruhnya terhadap individu maupun struktur sosial. Modal sosial merupakan sebuah faktor yang apabila tidak tersedia akan mengakibatkan suatu tujuan susah tercapai.

Bourdieu (1986) mendefinisikan modal sosial sebagai faktor yang merupakan akumulasi dari segala yang telah dilakukan oleh seseorang dalam kelompok masyarakatnya. Modal sosial memungkinkan kelompok masyarakat untuk mencapai sesuatu (Coleman, 1988; Putnam, 1995). Putnam (1995) juga menyatakan bahwa modal sosial mendorong orangorang dalam suatu masyarakat untuk mau terlibat dalam kegiatan kolektif dengan anggapan bahwa anggota masyarakatnya yang lain juga akan melakukan hal yang sama. Pakar lain menyatakan bahwa modal sosial 
mendorong terjadinya koordinasi dan kerjasama (Putnam, 1995; Pretty \& Ward, 2001). Keberadaan modal sosial mengakibatkan anggota masyarakat tidak akan melakukan hal-hal yang merugikan, karena orang lain tidak akan melakukan hal tersebut (Pretty \& Ward, 2001).

Modal sosial terdiri atas beberapa bentuk. Coleman (1988) menyatakan bahwa modal sosial terdiri atas dua hal yaitu struktur sosial dan pelaku, serta bersifat produktif. Putnam (1995) menyatakan bahwa modal sosial terdiri atas jaringan, norma dan kepercayaan antara anggota masyarakat. Pretty \& Ward (2001) menyatakan ada 4 bentuk modal sosial yaitu kepercayaan (relations of trust), hubungan timbal balik (reciprocity and exchanges), aturan, norma dan sanksi (common rules, norms and sanctions), dan keterhubungan, jaringan dan kelompok (connectedness, networks and groups).

Masyarakat Bali yang tergabung dalam desa adat (pakraman) memiliki suatu modal sosial yang berupa sistem kesejahteraan (Meniarta et al, 2009). Bentuk-bentuk modal sosial masyarakat Desa Adat di Bali terdiri atas nilai, institusi dan mekanisme. Nilai yang dianut masyarakat adat di Bali bahwa semua warga adalah bersaudara (menyama-braya). Selain itu, kebahagiaan dan kesedihan dirasakan bersama (suka-duka). Nilai tersebut menjadi pendorong warga desa adat untuk ikut dalam urunan, bergotong royong, saling memberi (ngejot) maupun arisan, yang dilakukan untuk mendistribusikan kembali kesejahteraan kepada seluruh warga desa adat (krama) secara adil.

Dikaitkan dengan pengembangan pariwisata berbasis masyarakat, semangat kebersamaan yang muncul dari nilai, institusi dan mekanisme adat dapat memunculkan semangat untuk bekerja secara kolektif dalam mencapai suatu tujuan bersama. Semangat kolektif tersebut diistilahkan sebagai "sense of community", yaitu kualitas hubungan antar manusia yang mengakibatkan mereka dapat hidup bersama secara sehat dan berkelanjutan (Bopp et al, 2000 dalam Aref, 2011). Sense of community mampu mendorong partisipasi masyarakat dalam pengembangan pariwisata (Aref, 2011).

Artikel ini merupakan hasil penelitian yang dilakukan dengan pendekatan kualitatif. Data yang dikumpulkan berupa keterangan para informan terkait alasan penataan Pantai Kedonganan, proses penataan, serta kendala dan faktor pendukung penataan. Selain itu, dikumpulkan pula data terkait aspek geografis, demografis, aspek pemerintahan dan kepariwisataan di Pantai Kedonganan. Data diperoleh melalui wawancara mendalam terhadap delapan informan yang ditentukan secara purposive. Studi dokumentasi dilakukan terhadap beberapa dokumen yang diperoleh dari Kantor Kelurahan Kedonganan dan Sekretariat Desa Adat Kedonganan. Selain itu, dilakukan pula observasi di lokasi penelitian, yaitu Pantai Kedonganan. Data yang terkumpul dianalisis secara kualitatif dan hasilnya disampaikan dalam bentuk uraian dan gambar model. 


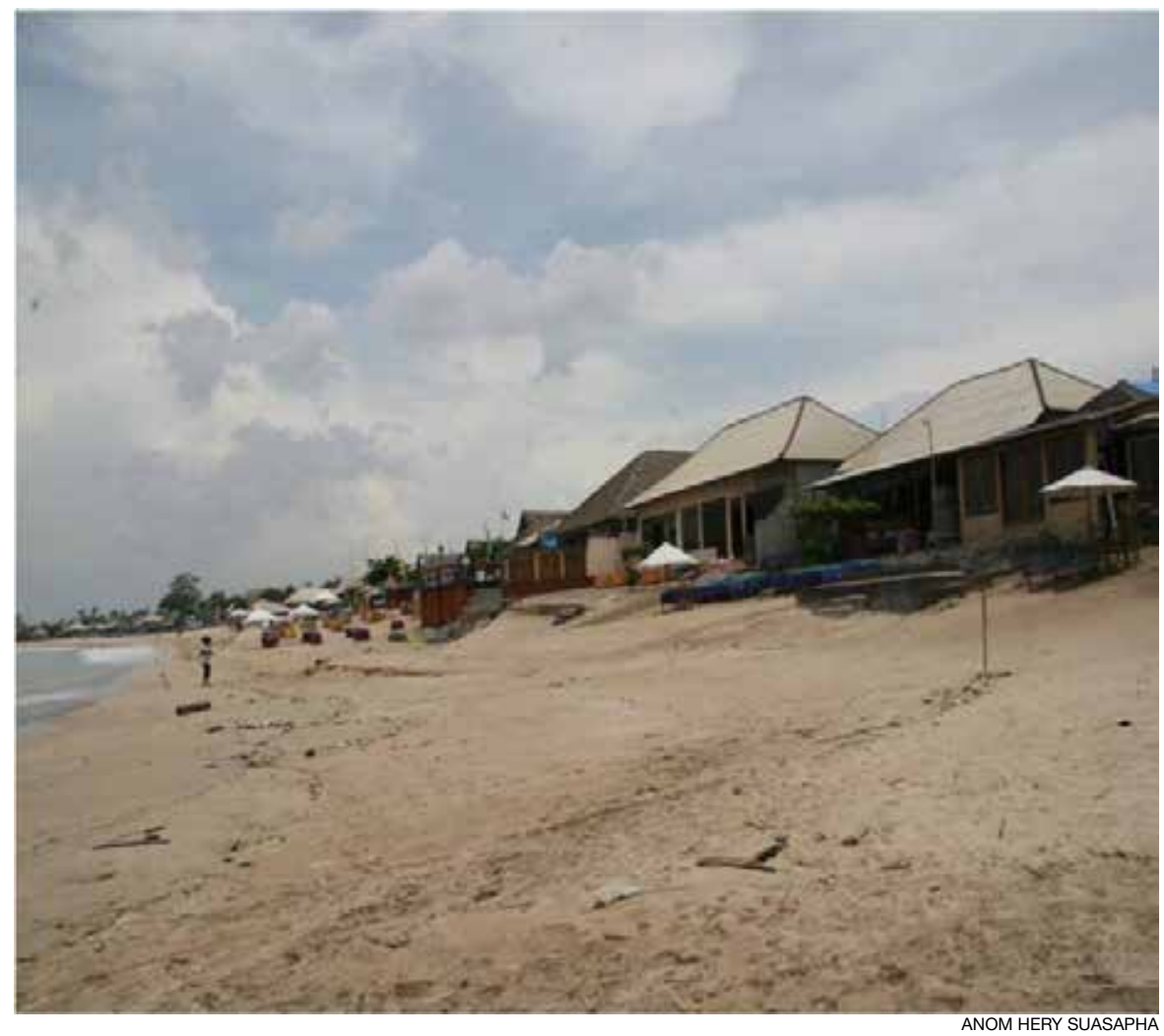

Foto 1. Kondisi Pantai Kedonganan sebelum penataan ulang.

\section{Penataan Kafe di Pantai Kedonganan}

Pada tahun 2006, di Pantai Kedonganan telah berdiri sebanyak 76 kafe. Bangunan-bangunan kafe tersebut didirikan berjejer di sepanjang garis Pantai Kedonganan semenjak tahun 1995, untuk memastikan pengunjung yang makan memperoleh pemandangan (view) suasana Pantai Kedonganan dan lalu-lalang pesawat yang mendarat dan lepas-landas di Bandara Internasional I Gusti Ngurah Rai.

Pendirian kafe tersebut dilakukan tanpa koordinasi. Warga yang ingin mendirikan kafe datang ke Pantai Kedonganan kemudian memasang patok untuk mengkapling wilayahnya. Mantan Jero Bendesa Adat Kedonganan, Bapak I Ketut Mudra menyatakan bahwa Bendesa Adat yang menjabat pada waktu itu tidak bisa berbuat banyak terhadap fenomena tersebut, sehingga jumlah kafe terus bertambah dan mencapai angka 67 kafe pada tahun 2006. Hal yang sama juga disampaikan oleh salah seorang pemilik kafe pertama di Pantai Kedonganan yaitu Bapak I Made Sukra, yang menyatakan bahwa pendirian kafe waktu itu tanpa koordinasi (Foto 1).

Ketika garis Pantai Kedonganan telah didominasi oleh bangunan kafe, 
timbul berbagai masalah lingkungan, sosial-budaya dan ekonomi. Di bidang lingkungan, fenomena maraknya kafe mengakibatkan Pantai Kedonganan terlihat tidak rapi dan tidak mencerminkan kondisi dan suasana pantai yang banyak dikunjungi wisatawan. Kafe yang ada membuang limbah langsung ke pasir pantai sehingga menambah buruk kondisi lingkungan Pantai Kedonganan.

Di bidang sosial-budaya, keberadaan bangunan kafe membuat warga Desa Adat Kedonganan merasa malu ketika ingin berenang atau berolahraga di Pantai Kedonganan karena mereka khawatir menjadi tontonan pengunjung yang sedang makan. Bangunan-bangunan kafe menghalangi pelaksanaan upacara Melasti, yaitu prosesi penyucian sarana persembahyangan yang dilakukan warga Desa Adat Kedonganan di Pantai Kedonganan.

Keberadaan kafe tidak memberikan manfaat ekonomi yang seharusnya diterima oleh warga. Jumlah kafe yang banyak dan kesamaan produk yang dijual seperti makanan hasil olahan ikan laut (sea food) menimbulkan perang harga. Perang harga selanjutnya menimbulkan terjadinya kecurangan terhadap timbangan ikan (untuk memaksimalkan keuntungan) dan berujung pada perang pemberian komisi kepada pramuwisata dan sopir yang mengantar pengunjung ke Pantai Kedonganan. Kondisi tersebut mengakibatkan terjadi banyak perpindahan kepemilikan kafe dari warga Desa Adat Kedonganan kepada warga luar, yang secara permodalan lebih kuat. Ada kekhawatiran warga bahwa mereka hanya akan menjadi penonton perkembangan pariwisata di daerahnya sendiri (Wawancara dengan I Wayan Mertha, 29 Desember 2014; I Ketut Mudra, 1 Juli 2014; I Ketut Madra, 14 Juli 2014 dan I Made Sukra, 26 Mei 2014). Berbagai permasalahan tersebut mendorong para pemuda untuk mengusulkan dilakukannya penataan ulang. Usulan tersebut disampaikan kepada Jro Bendesa Adat, dan memperoleh respon positif pada masa Jro Bendesa I Ketut Mudra.

\subsection{Penataan Pantai Kedonganan Tahap I}

Penataan tahap I ditandai dengan munculnya kesadaran di antara pemuda Kedonganan untuk menata kepariwisataan di Pantai Kedonganan (Wawancara dengan I Wayan Mertha, 29 Desember 2014). Rencana penataan tersebut selanjutnya disampaikan kepada Jro Bendesa I Ketut Mudra. Usulan penataan diterima dengan baik karena dalam usulan tersebut terkandung harapan dari seluruh warga Desa Adat Kedongaan untuk dapat menerima manfaat secara bersama-sama dari kepariwisataan yang dikembangkan di Pantai Kedonganan. Penataan Pantai Kedonganan merupakan aspirasi dan inisiatif seluruh warga Desa Adat Kedonganan (Wawancara dengan I Ketut Mudra, 1 Juli 2014; I Ketut Madra, 14 Juli 2014 dan I Made Sukra, 26 Mei 2014).

Berdasarkan usulan dari warga, Jro Bendesa menggandeng Lurah Kedonganan dan Ketua LPM Kedonganan untuk membentuk panitia 
penataan melalui Surat Keputusan Bersama. Panitia penataan bertugas untuk membuat rencana penataan dan mengupayakan adanya kajian ilmiah berupa penelitian untuk memperoleh informasi awal untuk pembuatan rencana penataan.

Kajian ilmiah terkait potensi wisata, aspek sosial-ekonomi-budaya masyarakat Kedonganan dan konsep penataan dapat terwujud melalui kerjasama dengan dua lembaga pendidikan tinggi pariwisata, yaitu Sekolah Tinggi Pariwisata (STP) Nusa Dua Bali dan Sekolah Tinggi Pariwisata (STP) Bandung. Penelitian tersebut diselesaikan pada tahun 2005 dan hasilnya disosialisasikan kepada seluruh warga. Rekomendasi penelitian terpenting yang disosialisasikan pada waktu itu adalah 67 kafe yang ada harus dikurangi jumlahnya menjadi 12. Selain itu, direkomendasikan pula konsep penataan Pantai Kedonganan yang mengedepankan prinsip keberlanjutan (sustainability) dengan konsep pariwisata berbasis masyarakat.

Rekomendasi penelitian tersebut dituangkan ke dalam perencanaan penataan Pantai Kedonganan. Rencana tersebut kemudian disosialisasikan kepada seluruh warga Desa Adat Kedonganan yang tersebar di enam banjar. Sosialisasi dilakukan dalam forum paruman banjar. Dari hasil sosialisasi, diketahui bahwa warga menyetujui rencana penataan dengan syarat jumlah kafe ditambah sehingga berjumlah 24. Hal tersebut mengindikasikan adanya partisipasi aktif warga Desa Adat Kedonganan. Indikasi tersebut terlihat dari terlibatnya warga dalam menentukan dan memutuskan isi rencana penataan Pantai Kedonganan, dan bukan hanya diam dan menerima usulan yang disampaikan oleh panitia penataan.

Usulan warga untuk menambah jumlah kafe menjadi 24 selanjutnya dijadikan dasar untuk melakukan perubahan terhadap rencana yang sudah disusun. Rencana tersebut selanjutnya disampaikan kepada Pemerintah Daerah Kabupaten Badung untuk mendapatkan persetujuan. Pemerintah Kabupaten Badung menyetujui rencana tersebut dan mengeluarkan Rekomendasi Nomor 603 Tahun 2006 yang isinya menyerahkan pengelolaan kepariwisataan di Pantai Kedongaan kepada Desa Adat Kedonganan, dalam bentuk pembangunan 24 kafe yang akan dimiliki oleh seluruh warga Desa Adat Kedonganan.

Diterbitkannya Rekomendasi Nomor 603 Tahun 2006 menjadi dasar bagi Desa Adat Kedonganan untuk melaksanakan penataan. Pada Desember 2006, proses penataan dengan membongkar 67 kafe telah dirampungkan. Dalam proses pembongkaran, terjadi penolakan oleh beberapa pemilik dari 67 kafe. Penolakan tersebut didasari oleh alasan bahwa mereka adalah pionir pendiri kafe di Pantai Kedonganan, yang akan merasa rugi apabila kafenya diratakan. (Wawancara dengan I Ketut Mudra, 1 Juli 2014; I Ketut Madra, 14 Juli 2014). Warga yang menolak tidak menginginkan adanya kepemilikan secara komunal terhadap kafe. Mereka menginginkan kepemilikan perorangan (wawancara 
dengan I Wayan Sada, 25 Desember 2014). Penolakan tersebut menimbulkan benturan fisik dan penghinaan oleh warga yang menolak kepada para tokoh Desa Adat Kedonganan sehingga mendorong dilaporkannya kejadian tersebut ke Poltabes Denpasar. Konflik tersebut diselesaikan secara adat. Warga yang menolak diminta menyampaikan permohonan maaf kepada seluruh warga Desa Adat Kedonganan di enam banjar. Selain itu, mereka diminta menyetujui dilaksanakannya penataan ulang terhadap cafe yang ada. Melalui penyelesaian konflik secara adat, penolakan terhadap rencana penataan tidak ada lagi, sehingga proses penataan dapat dilanjutkan. Warga yang sempat menolak tetap mendapatkan hak untuk ikut memiliki kafe yang dibangun setelah penataan ulang, dengan menjadi anggota salah satu kelompok kafe di banjar-nya

Setelah 67 kafe dibongkar, pada bulan Januari 2007 sebanyak 24 kafe dibangun kembali di tempat-tempat yang telah ditentukan. Biaya pembangunan diperoleh dari LPD Kedonganan. Bersamaan dengan pembangunan 24 kafe (bulan Pebruari 2007) tiga lembaga yaitu Desa Adat, Kelurahan dan LPM Kedonganan membentuk Badan Pengelola Kawasan Pariwisata Pantai Kedonganan (BPKP2K), organisasi yang ditugaskan mengelola kepariwisataan di Pantai Kedonganan termasuk 24 kafe. Setelah itu, tiga lembaga tersebut juga membentuk kepanitiaan untuk menyusun peraturan desa adat (perarem) yang akan menjadi pedoman penyelenggaraan usaha/pengelolaan 24 kafe dan kawasan Pantai Kedonganan.

\subsection{Penataan Pantai Kedonganan Tahap II}

Beroperasinya 24 kafe hasil Penataan Tahap I di Pantai Kedonganan semenjak Maret 2007 menghadapi beberapa masalah. Masalah tersebut berupa pemberian komisi melebihi ketentuan dalam perarem, serta adanya timbangan ikan yang tidak menunjukkan bobot ikan yang sebenarnya di beberapa kafe. Masalah tersebut mendorong dilaksanakannya penataan Pantai Kedonganan Tahap II.

Penataan Pantai Kedonganan Tahap II dimulai dengan pembentukan Panitia Penataan Tahap II melalui Surat Keputusan Bersama yang ditandatangani oleh pimpinan tiga lembaga, yaitu desa adat, kelurahan dan LPM Kedonganan. Panitia tersebut ditugaskan untuk membuat rencana penataan (blue-print), serta menyusun perarem untuk menyempurnakan perarem yang telah disusun sebelumnya.

Setelah rencana penataan selesai disusun, tiga lembaga, panitia penataan dan BPKP2K kembali melakukan pertemuan dengan Pemerintah Daerah Kabupaten Badung untuk memohon izin sebagai pengelola kepariwisataan di Pantai Kedonganan. Permohonan izin tersebut disetujui, ditandai dengan diterbitkannya Surat Keputusan Bupati Badung Nomor 1238/I/HK/2008 yang isinya memberikan izin kepada Desa Adat Kedonganan untuk mengelola kepariwisataan di Pantai Kedonganan. 


\section{Implementasi Prinsip-prinsip Pariwisata Berbasis Masyarakat}

Pengelolaan kepariwisataan di Pantai Kedonganan dilakukan dengan menerapkan empat prinsip pariwisata berbasis masyarakat. Prinsip-prinsip tersebut adalah (1) prinsip partisipasi masyarakat, (2) prinsip konservasi alam, (3) prinsip ekonomi lokal, dan (4) prinsip konservasi sosial-budaya.

Prinsip partisipasi masyarakat yang diimplementasikan terutama yang berkaitan dengan pelibatan warga Desa Adat Kedonganan untuk mengambil keputusan terkait rencana penataan Pantai Kedonganan. Selain itu, partisipasi masyarakat juga terwujud dalam kepemilikan seluruh warga Desa Adat Kedonganan terhadap 24 kafe yang ada, keikutsertaan dalam pembongkaran, dan keikutsertaan dalam mengawasi tata-kelola kawasan pariwisata Pantai Kedonganan.

Kepemilikan warga membuat kesejahteraan warga Desa Adat Kedonganan meningkat (Wawancara dengan Sudena, 29 Mei 2014; I Ketut Mudra, 14 Juli 2014). Selain itu, jumlah aset Desa Adat Kedonganan dan LPD Kedonganan juga meningkat (Wawancara dengan I Ketut Madra, 14 Juli 2014). Hal tersebut menunjukkan terimplementasikannya prinsip ekonomi lokal dalam pengelolaan kepariwisataan di Pantai Kedonganan.

Peningkatan kesejahteraan masyarakat berkontribusi terhadap pelestarian lingkungan. Sebelum berkembangnya pariwisata di Pantai Kedonganan, warga memperoleh penghasilan dari penggalian terumbu karang untuk dijadikan gamping. Selain itu, warga juga menebang pohon bakau sebagai kayu bakar untuk memasak (Wawancara dengan I Ketut Madra, 14 Juli 2014). Setelah penataan Pantai Kedonganan dilakukan, kesejahteraan warga Desa Adat Kedonganan meningkat, sehingga warga tidak lagi menggali terumbu karang sebagai sumber penghasilan, atau pun menebang pohon bakau sebagai sumber kayu bakar.

Penerapan prinsip konservasi alam juga terlihat dari pengurangan jumlah kafe menjadi 24 dari sebelumnya berjumlah 76 . Pengurangan tersebut mengurangi tekanan terhadap lingkungan serta mengurangi jumlah limbah yang diproduksi. Selain itu, dilakukan zonasi untuk mengakomodir beberapa fungsi Pantai Kedonganan, yaitu sebagai tempat dilaksanakannya upacara keagamaan, tempat warga lokal berekreasi dan tempat penambatan jukung (perahu) milik nelayan.

Penerapan pinsip konservasi alam, khususnya zonasi mendukung penerapan pinsip konservasi sosial budaya dalam pengelolaan kepariwisataan Pantai Kedonganan. Penerapan prinsip konservasi budaya terlihat dari dibangunnya zona/area pemelisan, yaitu tempat yang khusus disediakan sebagai tempat untuk melaksanakan upacara melasti oleh warga Desa Adat Kedonganan.

Selain itu, keberadaan kafe juga memberikan kesempatan bagi muda-mudi Desa Adat Kedonganan yang memiliki keterampilan menari 
tradisional Bali untuk memperoleh penghasilan. Para penari tampil menghibur pengunjung yang sedang makan dan memperoleh penghasilan dari penampilannya. Hal tersebut menunjukkan bahwa selain berkontribusi dalam pelestarian kesenian tradisional Bali, penerapan prinsip konservasi budaya berimplikasi terhadap penyediaan sumber pendapatan tambahan bagi warga Desa Adat Kedonganan. Hal tersebut juga menunjukkan adanya keterkaitan di antara empat prinsip pariwisata berbasis masyarakat dalam pengelolaan kepariwisataan Pantai Kedonganan.

\section{Faktor Pendukung dan Penghambat}

Implementasi konsep pariwisata berbasis masyarakat di Pantai Kedonganan didukung oleh lima faktor. Faktor pertama adalah potensi wisata yang dimiliki oleh Pantai Kedonganan, faktor pendukung selanjutnya adalah adanya aspirasi warga Desa Adat Kedonganan, sinergi antara pemangku kepentingan kepariwisataan di Pantai Kedonganan, dukungan Pemerintah Daerah Kabupaten Badung, dan modal sosial yang dimiliki warga Desa Adat Kedonganan. Faktor yang menghambat implementasi pariwisata berbasis masyarakat di Pantai Kedonganan adalah penolakan sekelompok kecil warga dan ketidakpahaman warga terhadap status legalitas lahan Pantai Kedonganan.

Masalah yang dihadapi dalam pengembangan pariwisata berbasis masyarakat di Pantai Kedonganan adalah pelanggaran terhadap perarem (aturan atau kesepakatan tambahan) dan pelanggaran terhadap rencana penataan (blue print). Pelanggaran terhadap perarem terindikasi dari adanya perang harga di antara 24 kafe, pemberian komisi yang melebihi ketentuan dalam perarem yaitu maksimum 25\% dari harga makanan, dan timbangan ikan yang tidak menunjukkan bobot yang sebenarnya. Pelanggaran terhadap rencana penataan terlihat dari adanya beberapa bangunan yang seharusnya tidak ada, seperti Stasiun Pengisian Bahan Bakar Umum (SPBU) dan pembangunan dermaga yang didahului dengan pemasangan struktur penahan ombak di perairan Pantai Kedonganan (Wawancara dengan I Wayan Mertha, 29 Desember 2014). Masalah-masalah tersebut harus segera diatasi sehingga dampaknya tidak semakin buruk bagi kepariwisataan Pantai Kedonganan.

Solusi yang dapat diterapkan untuk mengatasi masalah-masalah tersebut adalah dengan melakukan sosialisasi secara rutin kepada seluruh stakeholders kepariwisataan Pantai Kedonganan oleh Desa Adat Kedonganan, Kelurahan Kedonganan, LPM Kedonganan dan BPKP2K. Materi sosialisasi dapat berupa isi dari perarem sehingga stakeholders semakin memahami dan mau mengikuti aturan-aturan tata kelola kafe dan kawasan Pantai Kedonganan. Selain itu, tujuan penataan dan pengelolaan kafe dan Pantai Kedonganan, masalah yang mendasari penataan ulang dan manfaat yang telah dirasakan setelah penataan ulang juga perlu terus 
disosialisasikan kepada seluruh stakeholder sehingga kesamaan persepsi di antara mereka tetap terjaga.

Solusi lain yang dapat dilakukan adalah dengan terus melakukan pendekatan terhadap Pemerintah Daerah Kabupaten Badung untuk tetap memberikan dukungan terhadap Desa Adat Kedonganan sebagai pengelola Pantai Kedonganan. Desa Adat Kedonganan, Kelurahan Kedonganan, LPM Kedonganan dan BPKP2K perlu melakukan advokasi untuk memastikan penataan Pantai Kedonganan dapat menjadi bagian integral dari program pengelolaan dan pengembangan kawasan pesisir di Kabupaten Badung. Hal ini penting untuk menjaga keberlanjutan kepariwisataan di Pantai Kedonganan. Advokasi dilakukan melalui lobby terhadap Pemerintah Daerah Kabupaten Badung maupun DPRD Badung.

\section{Model CBT dalam Pengelolaan Pantai Kedonganan}

Inisiatif pengembangan pariwisata berbasis masyarakat dalam pengelolaan Pantai Kedonganan sebagai daya tarik wisata muncul dari para pemuda Desa Adat Kedonganan. Inisiatif tersebut mendapatkan dukungan dari seluruh warga, sehingga menjadi aspirasi seluruh warga Desa Adat Kedonganan. Hal tersebut menunjukkan bahwa penataan kepariwisataan di Pantai Kedonganan bukanlah sebuah kebijakan yang digariskan oleh pemerintah (top-down), melainkan bentuk inisiatif yang muncul dari warga (bottom-up). Inisiatif warga merupakan karakteristik utama pariwisata berbasis masyarakat (Asker et al, 2010; Tasci et al, 2013), karena aspirasi warga menunjukkan adanya partisipasi masyarakat dalam tahap perencanaan (Hausler \& Strasdas, 2002).

Inisiatif warga memperoleh dukungan dari tiga Lembaga di Kedonganan, yaitu Desa Adat, Kelurahan dan LPM Kedonganan. Tiga Lembaga selanjutnya membentuk panitia penataan yang tugasnya adalah membuat rencana penataan. Informasi dasar untuk pembuatan rencana diperoleh dari hasil penelitian yang dilakukan melalui kerjasama dengan dua lembaga pendidikan tinggi pariwisata. Hal tersebut menunjukkan adanya usaha kolaborasi dengan kalangan dunia pendidikan. Menurut Tasci et al (2013) kolaborasi tersebut adalah sangat penting untuk memberikan dukungan berupa hasil penelitian, membangun kesadaran warga dan meningkatkan kapasitas warga.

Setelah rencana penataan diselesaikan, dilakukan sosialisasi untuk mendapat tanggapan seluruh warga yang tersebar di enam banjar di Desa Adat Kedonganan. Sosialisasi menunjukkan dukungan warga Desa Adat Kedonganan terhadap rencana penataan, dengan catatan agar dilakukan perubahan. Rencana penataan menyatakan akan membangun 12 kafe, namun warga meminta agar dibangun 24 buah, yang nantinya dimiliki oleh seluruh warga Desa Adat Kedonganan yang tersebar di enam banjar. 
Hausler dan Strasdas (2002:26) menyatakan bahwa model keterlibatan masyarakat dalam pariwisata berbasis masyarakat dapat berupa menjual produk langsung kepada wisatawan ataupun melalui perantara, mengundang investor untuk membuka usaha di daerahnya, warga lokal mendirikan bisnisbisnis pariwisata, warga memiliki dan menjalankan usaha pariwisata secara komunal dan warga bekerjasama dengan investor untuk mendirikan usaha. Dalam konteks Kedonganan, keinginan warga untuk memiliki 24 kafe secara bersama-sama sesuai dengan model nomor empat yang disampaikan oleh Hausler \& Strasdas (2002), yaitu warga memiliki dan menjalankan usaha pariwisata secara komunal.

Keinginan warga tersebut menjadi dasar untuk memperbaiki rencana penataan. Rencana penataan yang telah diperbaiki disampaikan kepada Pemerintah Kabupaten Badung untuk memperoleh persetujuan. Pemerintah Kabupaten Badung menyetujui rencana yang disusun. Persetujuan tersebut ditandai dengan diterbitkannya Rekomendasi Bupati Badung Nomor 603 Tahun 2006 yang isinya menunjuk Desa Adat Kedonganan untuk melakukan penataan terhadap Pantai Kedonganan.

Rekomendasi Nomor 603 Tahun 2006 diperkuat lagi dengan dikeluarkannya Surat Keputusan Bupati Badung Nomor 1238/I/HK/2008 yang isinya memberikan izin kepada Desa Adat Kedonganan untuk melakukan penataan terhadap Pantai Kedonganan. Dukungan Pemerintah Kabupaten Badung sangat penting bagi penataan Pantai Kedonganan, karena pemerintah merupakan pihak yang mampu menyediakan dukungan dalam bentuk kebijakan yang memungkinkan pelaksanaan pariwisata berbasis masyarakat (Tasci et al, 2013). Dukungan dana untuk penataan ulang diperoleh dari Lembaga Perkreditan Desa (LPD) Kedonganan dalam bentuk pinjaman lunak, tanpa jaminan (Wawancara dengan I Ketut Mudra, 1 Juli 2014; I Ketut Madra, 14 Juli 2014).

Inisiatif warga, serta dukungan tiga Lembaga, Pemerintah Kabupaten Badung dan LPD Kedonganan terhadap inisiatif tersebut mengindikasikan adanya sinergi yang baik antara stakeholder kepariwisataan di Pantai Kedonganan. Tasci et al (2013) menyatakan bahwa sinergi tersebut sangat dibutuhkan agar konsep pariwisata berbasis masyarakat dapat diimplementasikan dengan baik.

Selain melakukan penataan ulang terhadap kafe, Desa Adat Kedonganan bersama Kelurahan dan LPM Kedonganan membentuk Badan Pengelola Kawasan Pariwisata Pantai Kedonganan (BPKP2K). Organisasi tersebut bertugas sebagai pengelola kepariwisataan di Pantai Kedonganan termasuk 24 kafe yang dibangun setelah penataan ulang. BPKP2K melakukan tatakelola terhadap Kawasan Pantai Kedonganan berdasarkan perarem, yaitu peraturan yang hanya berlaku di Desa Adat Kedonganan yang mengatur Pantai Kedonganan dan kafe yang ada. 


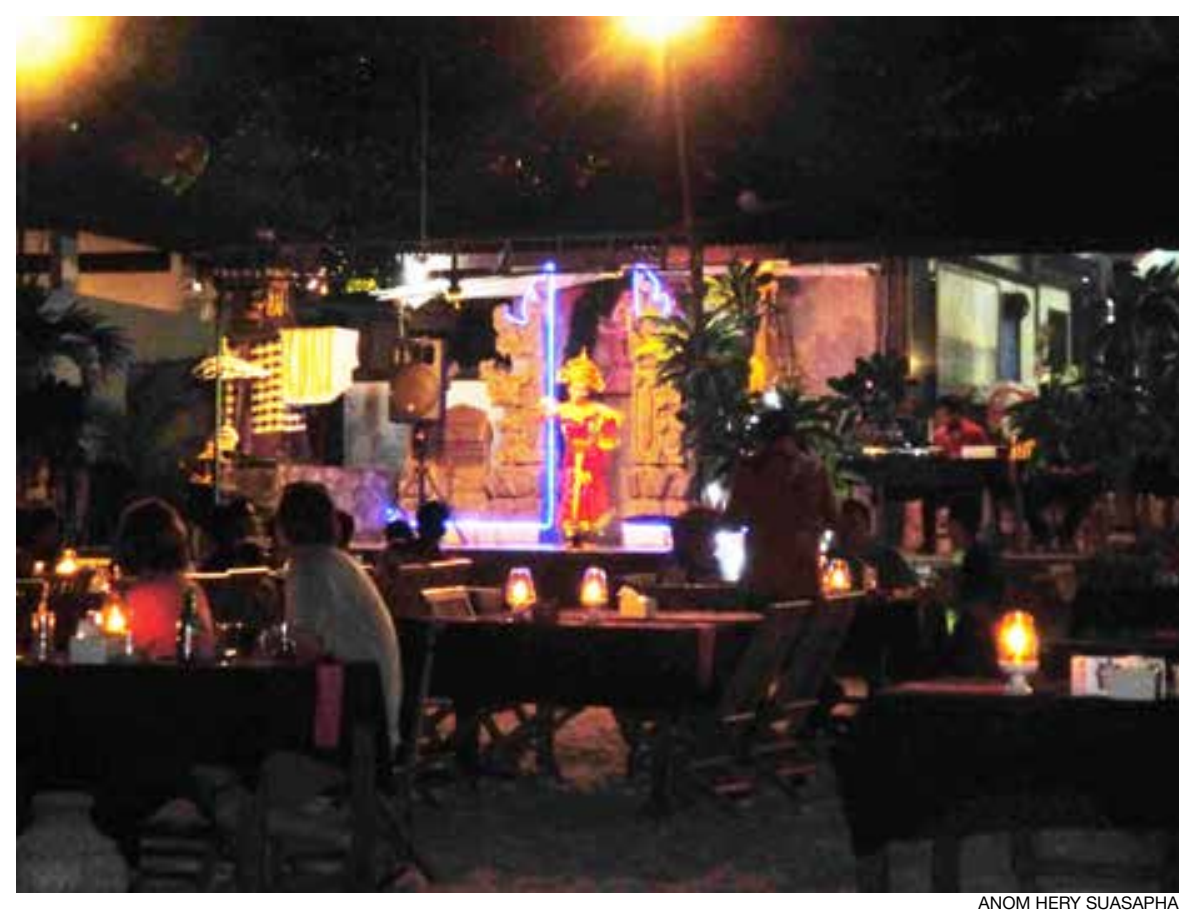

Foto 2. Sebuah cafe di Kedonganan mementaskan tari Bali sebagai hiburan.

Pembentukan BPKP2K sebagai lembaga pengelola kawasan Pantai Kedonganan sesungguhnya merupakan upaya untuk menyediakan kepemimpinan (leadership) yang diistilahkan sebagai destination leadership/ organization. (Gunn, 1994). Pendapat Gunn (1994:279) tentang perlunya menyediakan kepemimpinan dalam mengelola kawasan wisata sejalan dengan pendapat Morrison (2013:5). Morrison menyatakan bahwa sebuah kawasan pariwisata memerlukan upaya-upaya yang terkoordinir dalam hal perencanaan, pengembangan maupun pemasarannya.

Morrison lebih lanjut menyatakan bahwa koordinasi yang baik dapat dicapai melalui pembentukan Destination Management Organization (DMO), yang merupakan merupakan organisasi/lembaga pengelola yang melaksanakan empat peran penting bagi sebuah kawasan, yaitu sebagai pemimpin dan koordinator, melaksanakan kegiatan pemasaran, menciptakan lingkungan fisik maupun non-fisik yang mendukung pencapaian tujuan, serta sebagai pelaksana. Dalam konteks pariwisata berbasis masyarakat, Hausler \& Strasdas (2002:28) menyatakan bahwa pembentukan organisasi/ lembaga pengelola tersebut diarahkan agar berbentuk lembaga perwakilan, terdiri atas perwakilan warga, pemerintah setempat dan institusi lokal.

Perarem yang dijalankan oleh $\mathrm{BPKP} 2 \mathrm{~K}$ dalam mengelola kepariwisataan di Pantai Kedonganan merupakan cerminan dari empat prinsip pariwisata berbasis masyarakat yang diimplementasikan. Empat prinsip tersebut adalah 


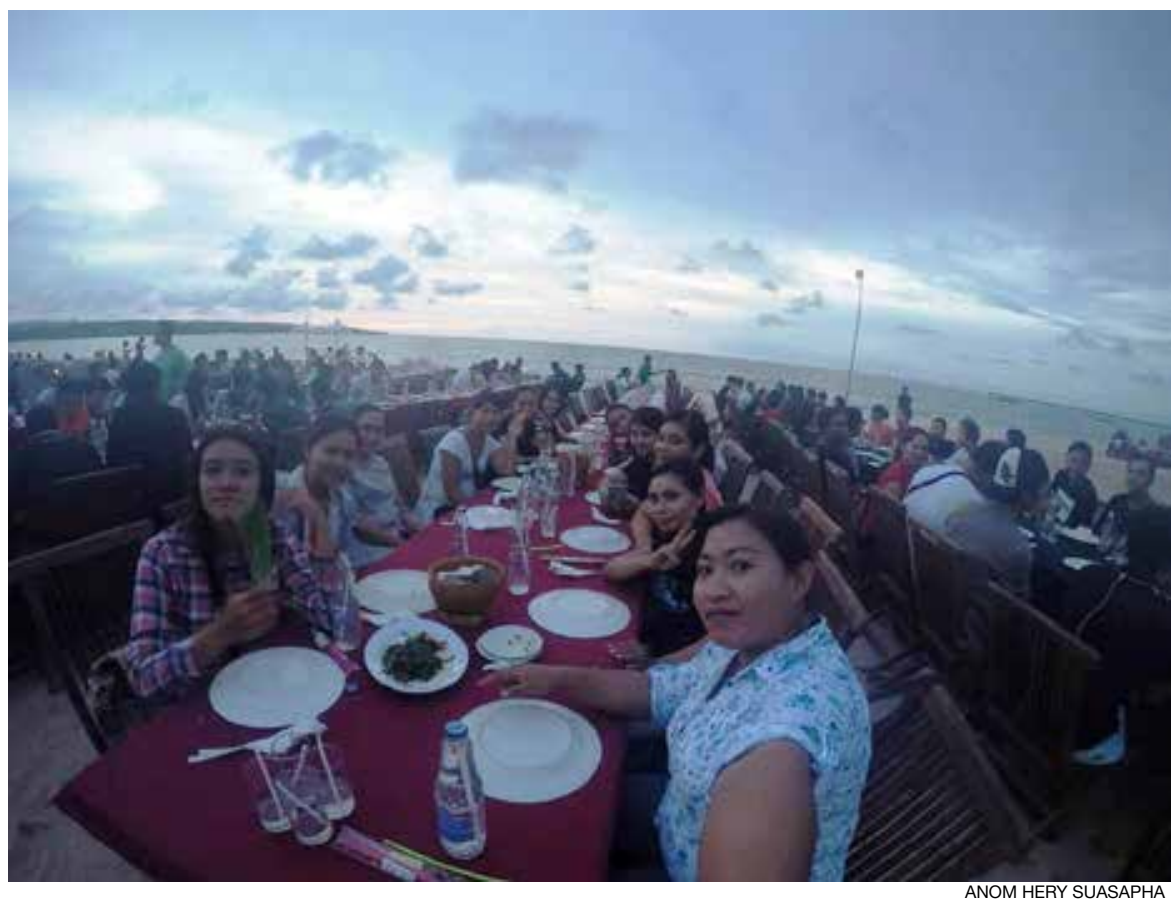

Foto 3. Suasana cafe di pantai Kedonganan, selalu ramai.

prinsip partisipasi masyarakat, prinsip konservasi alam, prinsip konservasi sosial-budaya dan prinsip ekonomi lokal. Prinsip-prinsip tersebut berkesesuaian dengan pencapaian tiga pilar pariwisata berbasis masyarakat (Asker et al, 2010). Melalui penerapan perarem secara konsisten, diharapkan kepariwisataan di Pantai Kedonganan dapat berjalan dalam kaidah-kaidah keberlanjutan, sehingga keberadaannya dapat berkontribusi positif terhadap lingkungan, sosial-budaya dan perekonomian warga Desa Adat Kedonganan (Foto 2).

Implementasi konsep pariwisata berbasis masyarakat dalam pengelolaan Pantai Kedonganan sangat dimudahkan oleh modal sosial (social capital) yang dimiliki oleh warga Desa Adat Kedonganan. Modal sosial tersebut berupa kepemimpinan (leadership), dan kepercayaan warga terhadap para tokoh adat, nilai (value) dan norma-norma (norms) tentang menyamabraya (berkeluarga) dan suka-duka serta paruman/sangkep. Modal sosial tersebut menumbuhkan sense of community (Aref, 2011), dan mengakibatkan warga mampu mewujudkan keinginan mereka bersama untuk mengelola kepariwisataan di Pantai Kedonganan. Dari uraian tersebut, berdasarkan pengalaman penerapan konsep pariwisata berbasis masyarakat dalam pengelolaan kepariwisataan di Pantai Kedonganan, dapat dirumuskan sebuah model hipotetis sebagai berikut: 


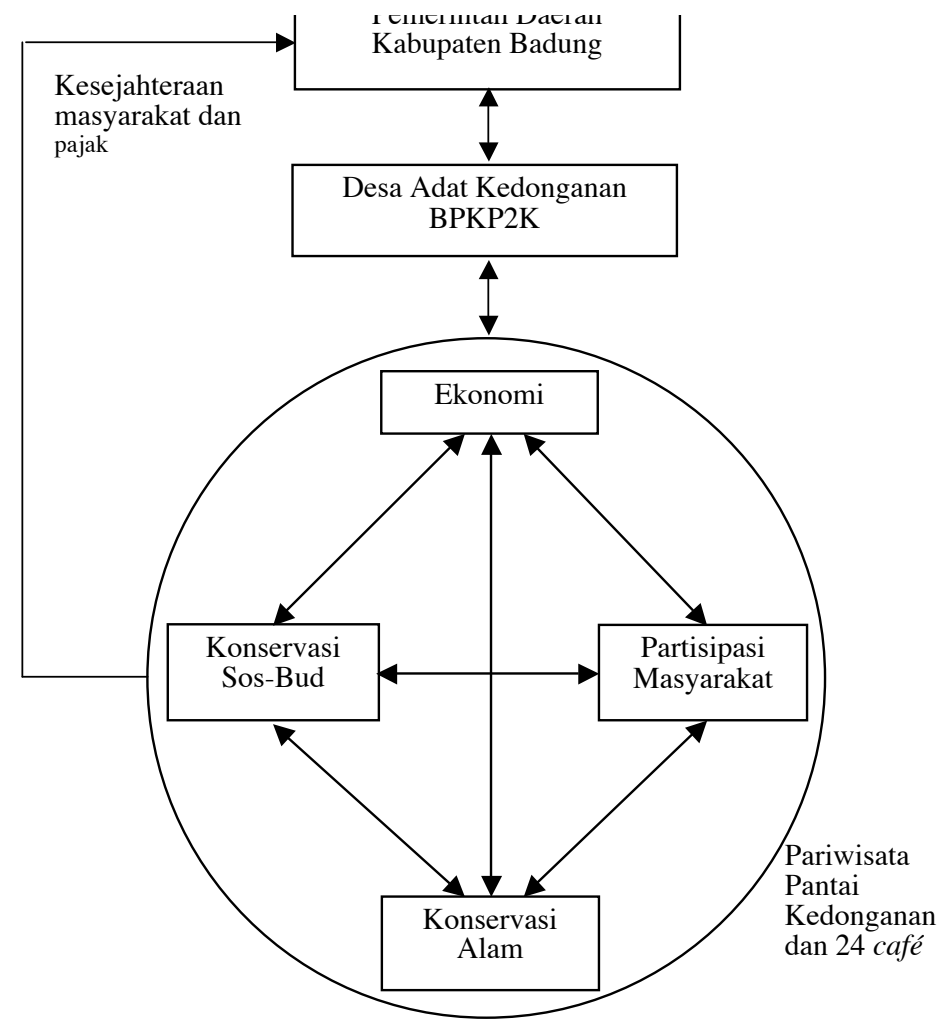

Model Hipotetis Pariwisata Berbasis Masyarakat dalam Pengelolaan Pantai Kedonganan sebagai Daya Tarik Wisata (Sumber: Peneliti, 2015)

\section{Penjelasan Model Hipotetis}

Empat prinsip pariwisata berbasis masyarakat dalam pengelolaan kepariwisataan Pantai Kedonganan terkristalisasi dalam perarem yaitu peraturan desa adat yang berlaku di Desa Adat Kedonganan mengenai Pantai Kedonganan dan 24 kafe. Perarem disusun oleh Desa Adat Kedonganan sebagai pihak yang memperoleh izin untuk menata dan mengelola Pantai Kedonganan dari Pemerintah Kabupaten Badung. Selain menyusun perarem, Desa Adat Kedonganan bersama Kelurahan Kedonganan dan LPM Kedonganan (3 Lembaga) membentuk BPKP2K untuk menegakkan aturanaturan dalam perarem. Model hipotetis tersebut dapat diimplementasikan di tempat lain dengan syarat masyarakat yang ingin mengimplementasikan harus cohesive atau memiliki kesamaan persepsi dan harapan mengenai pengembangan pariwisata yang akan dilakukan. Beberapa penyesuaian yang perlu dipertimbangkan adalah prinsip-prinsip pariwisata berbasis masyarakat yang perlu diimplementasikan, pemangku kepentingan yang terlibat dan jenis atraksi wisatanya. 


\section{Penutup}

Berdasarkan uraian di atas, dapat disimpulkan bahwa implementasi konsep pariwisata berbasis masyarakat di Pantai Kedonganan dilakukan dalam dua tahap. Tahap I terdiri atas delapan langkah sedangkan Tahap II terdiri atas tiga langkah. Dalam dua tahap penataan tersebut diimplementasikan empat prinsip pariwisata berbasis masyarakat yaitu prinsip partisipasi masyarakat, konservasi lingkungan, konservasi sosialbudaya, dan ekonomi lokal.

Implementasi didukung oleh lima faktor, sedangkan faktor penghambatnya ada dua. Model CBT yang diimplementasikan menunjukkan hubungan keterkaitan antara Pemerintah dengan Desa Adat sebagai pihak yang diizinkan oleh Pemerintah untuk mengelola kepariwisataan Pantai Kedonganan, dalam bentuk pengelolaan kawasan Pantai Kedonganan dan 24 kafe yang ada. Model hipotetis tersebut menunjukkan penerapan empat prinsip pariwisata berbasis masyarakat yang diawasi oleh BPKP2K, yaitu badan pengelola Kawasan Pantai Kedonganan. Model hipotetis tersebut dapat dijadikan inspirasi bagi pengembangan pariwisata berbasis masyarakat di tempat lain, dengan melakukan penyesuaian-penyesuaian yang dibutuhkan.

\section{Ucapan Terima Kasih}

Ucapan terimakasih disampaikan kepada Prof. Dr. I Nyoman Sirtha, SH., M.S., selaku pembimbing I dan Bapak Dr. Ir. I Made Adhika, MSP., selaku Pembimbing II yang sangat membantu penulis dalam penyelesaian penelitian. Terima kasih diucapkan kepada para informan, yaitu Drs. I Wayan Sandi, I Ketut Mudra, S.Ag., I Ketut Madra, SH., MH, I Wayan Mertha, SE., M.Si, I Made Sukra, Bapak Sudena, dan I Wayan Sada yang telah memberikan informasi penting untuk menyusun artikel ini. Selain itu, terima kasih juga diucapkan kepada I Nyoman Sudarta, SE (Lurah Kedonganan) dan Jro Bendesa I Ketut Puja, S.Ag yang telah menyediakan data sekunder serta mengizinkan dilakukannya penelitian di Pantai Kedonganan.

Ucapan terimakasih disampaikan kepada Prof. Dr. I Nyoman Darma Putra, M.Litt., dan Dr. Ir. Syamsul Alam Paturusi, MSP., sebagai Ketua Program Studi dan Sekretaris Program Studi Magister Kajian Pariwisata Program Pascasarjana Universitas Udayana, atas petunjuk dan bantuannya sehingga artikel ini bisa diselesaikan.

\section{Daftar Pustaka}

Anstein, Sherry S. 1969. A Ladder of Citizen Participation. AIP Journal. Aref, Faiborz. 2011. "Sense of Community and Participation for Tourism

Development”, Life Science Journal, Volume 8, Issue 1, 2011.

Asker, S., Boronyak, L., Carrard, N., and Paddon, M., 2010. Effective Community 
Based Tourism, A Best Practice Manual. Singapore: Sustainable Tourism Cooperative Research.

Coleman, James S. 1988. "Social Capital in the Creation of Human Capital”, American Journal of Sociology, Vol. 94, Supplement: Organizations and Institutions: Sociological and Economic Approaches to the Analysis of Social Structure (1988), pp. S95-S120..

Gunn, Clare A. 1994. Tourism Planning, Basics Concepts Cases. United States Of America: Taylor \& Francis.

Hausler, N., Strasdas, W. 2003. Training Manual For Community-based Tourism, Zschortau: Inwent.

Keputusan Bupati Badung Nomor 638 Tahun 2003 tentang Rencana Detail Tata Ruang Kecamatan Kuta.

Keputusan Bupati Badung Nomor 1238/01/HK/2010 tentang Persetujuan Pelaksanaan Penataan dan Pengelolaan Kawasan Pantai Kedonganan Kabupaten Badung oleh Desa Adat Kedonganan.

Keputusan Bendesa Adat Kedonganan, Lurah Kedonganan, LPM Kedonganan Nomor 02 Tahun 2008 tentang Pembentukan Panitia Pelaksana Pembuatan Perarem Kafe di Sepanjang Pantai Kedonganan.

Keputusan Bendesa Adat Kedonganan Nomor 01 Tahun 2010 tentang Penataan Pantai Kedonganan Dan Penunjukan Panitia Pelaksana Penataan Pantai Kedonganan Tahap II.

Keputusan Bendesa Adat Kedonganan Nomor 01 Tahun 2012 tentang Perarem Pantai dan Kafe.

Lopez-Guzman, Tomas., Sanchez-Canizarez, Sandra., Pavon, Victor. 2011. "Community-Based Tourism In Developing Countries, a Case Study. Tourismos: an international multidisciplinary" Journal of Tourism, Volume 6, Number 1, Spring 2011, pp. 69-84.

Meniarta, I Ketut., Mas’udi, Wawan., Dwipayana, A.A.G.N. Ari. 2009. Dinamika Sistem Kesejahteraan dan Modal Sosial di Masyarakat Banjar Pakraman-Bali. Jurnal Ilmu Sosial dan Ilmu Politik Volume: 13, Nomor 2, November 2009. pp. 231-248.

Mill, Robert Christie., Morrison, Alastair M. 2012. The Tourism System. United States Of Amerika: Kendall Hunt Publishing Company.

Morrison, Alastair M. 2013. Marketing and Managing Tourism Destinations. London \& New York: Routledge.

Nurhidayati, Sri Endah. 2013. "Pengembangan Agrowisata Berkelanjutan Berbasis Komunitas di Kota Batu, Jawa Timur”. Disertasi. Yogyakarta : Universitas Gadjah Mada.

Okazaki, Etsuko. 2008. "A Community-Based Tourism Model: Its Conception and Use”, Journal of Sustainable Development, Volume: 16, No. 5, 2008.

Peraturan Desa Adat Kedonganan Tentang Kafe di Sepanjang Pantai Kedonganan. Pongponrat, Kannapa, Chantradoan, Naphawan Jane. 2012. "Mechanisme of Social 
Capital In Community Tourism Parsipatory Planning in Samui Island, Thailand", Tourismos: An International Multidisciplinary Journal of Tourism, Volume: 7, Number 1, Spring-Summer 2012, pp. 339-349 UDC: 338.48+640(050) 339.

Prasiasa, Dewa Putu Oka. 2013. Destinasi Pariwisata Berbasis Masyarakat. Jakarta: Salemba Humanika.

Pretty, Jules N. 1995. Participatory Learning For Sustainable Agiculture. World Development, Vol: 23. No. 8. pp $1247-1263,1995$.

Pretty, Jules N., Ward, Hugh. 2001. Social Capital And The Environment. World Development Vol: 29, No. 2, pp. 209 - 227, 2001 Elsevier Science Ltd.

Putnam, Robert D. 1995. Bowling Alone: America's Declining Social Capital. Journal of Democracy 6:1, Jan 1995, 65-78.

Razzaq, Abdul Rasid Abdul., Mustafa, Mohamad Zaid., Suradin, Ali., Hassan, Razali., Hamzah , Amran., Khalifah , Zainab. 2011. Community Capasity Building for Sustainable Tourism Development, Experience From Miso Walay Homestay. Business and Management Review Vol. 2(5) pp. 10 - 19 July, 2012.

Sardana, I Nyoman. 2013. "Implikasi Pengaturan Usaha Pariwisata Wiayah Pesisir Terhadap Hak-hak masyarakat adat di Desa Adat Kedonganan dan Kuta. Kecamatan Kuta, Kabupaten Badung Provinsi Bali”. Tesis. Denpasar: Universitas Udayana.

Satria, Arif., Matsuda, Yoshiaki., dan Sano, Masaaki. 2005. Questioning Community Based Coral Reef Management System, Case Study of Awig-Awig in Gili Indah Indonesia. Environment, Development and Sustainability (2006) 8: 99-118.

Widowati, Sri 2012. "Kajian Potensi Serta Evaluasi Penerapan Prinsip-prinsip Dan

Kriteria Ekowisata di Kawasan Taman Wisata Alam Kawah Ijen Desa Taman Sari”. Tesis. Denpasar: Universitas Udayana.

Tasci, Asli D.A., Semrad, Kelly J. and Yilmaz, Semih S., 2013, Community Based Tourism Finding The Equilibrium in COMCEC Context, Setting the Pathway for the Future. Ankara: COMCEC Coordination Office.

Tzanakis, Michael. 2013. Social capital in Bourdieu's, Coleman's and Putnam's theory: empirical evidence and emergent measurement issues. Educate, Vol. 13, No. 2, 2013, p. 2-23.

\section{Profil Penulis}

Anom Hery Suasapha adalah alumnus Program Magister (S2) Kajian Pariwisata, Program Pascasarjana Univesitas Udayana. Ia menyelesaikan pendidikan Diploma IV di Sekolah Tinggi Pariwisata (STP) Nusa Dua Bali, di bidang Manajemen Kepariwisataan. Saat ini dia bertugas sebagai Pengelola Laboratorium Kepariwisataan juga sekaligus sebagai tenaga pengajar di STP Nusa Dua Bali 